\title{
THE PROTO-GERMANIC PLUPERFECT
}

\author{
FREDERIK KORTLANDT
}

The Germanic perfect presents (Präteritopräsentien) form a past tense by adding the endings of the weak preterit to the stem of the past participle, e.g. Go. wissa 'knew'. This is a recent formation (cf. Kortlandt 1989). We may therefore ask ourselves if we can reconstruct the earlier formation which was ousted by the weak preterit. We may also try to recover the motivation for the replacement.

There was no pluperfect in Proto-Indo-European. In Greek we find a derivative stem (w)eidè- 'knew', seemingly with the same suffix as in Slavic věder-. If such a formation had existed in Germanic, it would hardly have been replaced by *wissē-, cf. Go. witaida 'observed', which corresponds to Latin vidē-. ${ }^{1}$

The Vedic pluperfect can be defined as a perfect stem with secondary (aorist, imperfect) endings, e.g. ávedam 'I knew'(cf. especially Thieme 1929). This formation, which is occasionally found in Greek, may also have existed in Germanic. Indeed, I think that the hypothesis of a former pluperfect with secondary endings offers an explanation for a number of unclear points in Germanic historical morphology.

The interpretation of Go. ( $n i$ ) ogs ( $p u s)$ '(do not) fear' as an injunctive (Hirt, Meid), subjunctive (J. Schmidt, Bammesberger), or irregular optative (Scherer, Hiersche) is not supported by independent evidence and must therefore be rejected (see Bammesberger 1986 for references and discussion). The form evidently represents a perfect stem with a secondary ending.

It is difficult to separate OHG. ni curi 'noli', Tatian ni curet beside ni curit 'nolite' semantically from Go. ogs and formally from the West Germanic strong preterit indicative, e.g. OHG. 2nd sg. zugi, and pl. zugut 'drew'. The derivation of ( $n i$ ) curi from an aorist optative (cf. Bammesberger 1986: 676) is not supported by additional evidence and does not explain the plural form in -et, which can hardly be analogical. Moreover, the regular optative form ni churis in the 2nd Reichenauer Glossar suggests that the plural form curit replaced curet, not

\footnotetext{
${ }^{1}$ Prof. R.S.P. Beekes draws my attention to N. Berg's demonstration (1977) that Homeric èeíde 'he knew' actually represents ${ }^{\star} \bar{e}$ widee for ${ }^{\star} \bar{e}$ wide for ${ }^{\star}$ ewoide. This brings the Greek development closer to what is found in Vedic and proposed here for Germanic.
} 
the other way round. Thus the forms curi and curet appear to reflect the perfect stem with secondary ending ${ }^{\star}$-es, ${ }^{*}$-ete.

The usual view that the West Germanic 2nd sg. strong preterit ending $-i$ was taken from the aorist (indicative, injunctive or optative) cannot be correct because both the model and the motivation for such a replacement are lacking. Apart from ${ }^{\star} d \bar{e}-<{ }^{\star} d h \bar{e}$ - in the weak preterit and ${ }^{\star} s t \bar{o}-<{ }^{\star} s t \bar{a}$ - in the sixth class strong preterit, which are not suitable as a model, it is difficult to find traces of the aorist in Germanic. It is highly improbable that an isolated 2nd sg. aorist ending replaced the regular perfect ending in a limited area without leaving a trace in the more archaic dialects.

In the 2nd sg. ending $-i<{ }^{*}$-es belonged to a fully inflected paradigm, we can reconstruct 1 st sg. ${ }^{*}$-om and $3 \mathrm{rd} \mathrm{sg.}{ }^{*}$-et, both of which yielded a zero ending in the attested Germanic languages. The merger of these endings with those of the perfect makes clear why the category disappeared. What remains to be discussed is the mechanism which produced the distribution of the 2 nd sg. endings ${ }^{*}$-es and ${ }^{\star}$-ta which is actually attested in the material.

East and North Germanic preserved ${ }^{*}$ - $t a$ both in the perfect presents and in the strong preterit with the exception of stems in a long vowel, which adopted the weak endings in Scandinavian, e.g. 2nd sg. serer, 3rd sg. sere 'sowed'. This type has a 2nd sg. ending -st in Gothic saisost. Conversely, the ending - $t$ was added to the athematic 2 nd sg. form of the verb 'to be' in Scandinavian est, later ert. Thus, we find spread of ${ }^{*}$-es after a vowel in the preterit and spread of ${ }^{*}-t a$ after a consonant in the present tense. The West Germanic elimination of ${ }^{*}$-ta from the strong preterit and the addition of this ending in the athematic and sg. forms, e.g. OE. eart, bist, dēst, gōest, wilt, can be viewed as a continuation of the same development.

On the basis of what has been said I claim that we can reconstruct a thematic preterit of a perfect with secondary endings ${ }^{*}$-om, ${ }^{*}$-es, ${ }^{*}$-et, ${ }^{*}$-ete, at least for the perfect presents, where it was ousted by the newly formed weak preterit at a recent stage. The previous existence of this thematic formation explains the generalization of $-u$ - as a tense marker in the plural endings $-u m,-u d,-u n$ from ${ }^{\star}-m e,{ }^{\star}-t e,{ }^{\star}-n t$ in the perfect. It is hard to determine to what extent (if at all) the thematic formation supplied a real pluperfect to the strong preterit.

This brings us to the question of the model and the motivation for the creation of the pluperfect. While most simple verbs probably had at least an aorist or a perfect at an early stage, derived verbs only had an imperfect beside the present tense. This holds for the causatives and iteratives (1st class weak verbs), denominatives (1st and 2nd class weak verbs), and intensives (6th and 7 th class strong verbs with an original $o$-grade root vowel, cf. Kortlandt 1994). While the former categories had a thematic imperfect which was eventually replaced by the weak preterit, the intensives were an athematic reduplicated formation, cf. Vedic jánghanti 'strikes', ádardar 'pierced'. We may therefore wonder if Go. 
lailaik 'leaped', OHG. steroz 'struck', feang 'seized' directly continue an athematic imperfect. I think that this is not the case.

The remarkable fact about the development of the Indo-European intensives in Germanic is not that they may form a 7 th class strong preterit, which clearly represents the perfect, but that they do so only if the root structure prevented the formation of a 6th class strong preterit, which originated from the root aorist of roots in a long vowel (cf. Kortlandt 1994). This is particularly striking in view of the fact that the root *ar- 'plow', which probably had aorist meaning in the northern Indo-European languages because it has a je-present in Celtic, Germanic, Baltic and Slavic, did not join the 6th class of strong verbs but developed a 7 th class strong preterit in Old High German iar- and a weak preterit in the other languages. We would therefore expect to find Go. ${ }^{*}$ saislah, ${ }^{*}$ slahta or *slahida instead of sloh 'struck'. It follows that the athematic imperfect of the intensives remained distinct from both the root aorist and the perfect.

The solution to this anomaly seems to be that the athematic imperfect, like the athematic present, became thematicized at an early stage and did not therefore merge with either the root aorist or the perfect. A trace of the original athematic inflection may be preserved in Go. reiran 'to tremble', OE. rārian, OHG. rèren 'to roar', where the preterit Go. inreiraida 'quaked' suggests an original present stem ${ }^{*}$ reiroi-. This verb may have escaped early thematicization because its inflection was supported by the present stem ${ }^{\star}$ stai- 'stand' (cf. Kortlandt 1990: 8).

The remarkable fact that intensives with a root of the type $\mathrm{CaR}$ - or $\mathrm{CaC}$-, but not CaRC-, created a long vowel preterit on the analogy of the root ${ }^{*}$ stā- cannot be explained on the basis of a present stem ${ }^{*}$ stistā-, as in Greek histèmi 'I set up', or *stand-, as in Gothic. I think that the latter stem form must be derived from an athematic imperative of a nasal present ${ }^{*}$ standi, cf. Greek esthío 'I eat' from *ed-plus the Indo-European athematic imperative ending ${ }^{\star}$-dhi, as in Vedic addhi 'eat!'. It follows that we have to assume an inchoative nasal present ${ }^{\star}$ stan- beside the root aorist ${ }^{*} s t \bar{a}$-, which may be compared with Go. fulln- 'become full' beside the preterit fullnō- which apparently ousted the root aorist attested in Greek plẽto.

While the replacement of a root aorist by an imperfect in the case of fullnō- is a natural development, the creation of an aorist beside a regular imperfect on the anomalous pattern of ${ }^{\star}$ stan-, ${ }^{*} s t \bar{a}$ - is much more difficult to understand. If the original athematic imperfect ${ }^{*}$ pulnät became an aorist when the present tense was thematicized on the basis of $3 \mathrm{rd} \mathrm{pl.}{ }^{*}$ pulnanti, it must have been the reduplication which prevented the same thing happening to the intensives. This renders the presence of a semantic distinction between aorist and perfect at that stage highly probable. 
The creation of a new aorist beside the imperfect in these intensives and inchoatives also demonstrates the presence of a semantic distinction between aorist and imperfect at the time of the thematicization. This is nicely corroborated by the perfect present Go. kann 'know', which is evidently built on a thematicized imperfect *kunna-, cf. Vedic jānánti 'they know', ájānan 'they knew', Lith. žinóti 'to know'. The athematic imperfect which turned aorist ${ }^{\star} k u n n \bar{a}$ - was replaced by ${ }^{\star} k u n n \bar{e}$ - in Go. -kunnaida, obviously because the verb had durative meaning. The latter formation is found in competition with the original root aorist in ufkunnaida beside ufkunpa 'recognized'. The creation of an athematic aorist ${ }^{\star}$ naside $\overline{-}$ - 'saved' beside the thematic imperfect ${ }^{*}$ naseje/a- (cf. Kortlandt 1989: 107) can probably be dated to the same stage of development.

The thematic imperfect ${ }^{\star} k u n n a-$ was eventually ousted by the aorist kunpa 'knew'. If the same development can be demonstrated for a perfect preterit rather than a perfect present, this vindicates the hypothesis of a real pluperfect. I think that conclusive evidence is provided by the verbs Go. briggan 'to bring', brukjan 'to use', waurkjan 'to work', preterit brahta, bruhta, waurhta, OE. brōhte, brēac, and warhte beside worhte. Since these forms represent analogical weak preterits derived from strong preterit stems, their original function can hardly have been anything else than that of supplying a pluperfect to a strong preterit. As in the case of the past tense of perfect presents, I think that they replaced a thematic formation.

The thematic imperfect of intensives with a root of the type CaRC-was integrated into the perfect system, e.g. Go. lailaik 'leaped', OHG. steroz 'struck', feang 'seized', evidently because it was a reduplicated formation. This incidentally explains the absence of quantitative ablaut in the 7 th class strong preterit in Gothic. We can now assume that these perfects were created in a similar way as $k a n n$ was on the basis of ${ }^{\star} k u n n a-$. The paradigm reconstructed above for OHG. ni curi 'noli', ni curet 'nolite' fits into the picture rather nicely. When the pluperfect was lost as a tense, these forms survived in a modal function, like the Old Spanish pluperfect indicative in - $r a$ which has become a past subjunctive in the modern language. ${ }^{2}$

The theory developed here provides an explanation for the remarkable redundancy which characterizes the personal endings in the oldest Germanic material, e.g. Go. $-a,-i s,-i p,-a m,-i p,-$ and after a present stem versus $-\varnothing,-t,-\varnothing,-u m,-u p,-u n$ after a preterit stem versus - $a u,-s,-\emptyset,-m a,-p,-n a$ after an optative stem. This awkward system becomes understandable if it resulted from the loss of an imperfect and a pluperfect which were formed from the present and preterit stems by the addition of a set of secondary thematic

${ }^{2}$ On the meaning of the Dutch imperative in relation to present and preterit tense forms see Proeme 1984 . 
endings which regularly developed into $-\varnothing,-s,-\varnothing,-a m,-i p,{ }^{*}-a n$. Note that the function of the thematic vowel was particularly unfortunate because it distinguished on the one hand the present and imperfect from the weak preterit (aorist) and on the other the pluperfect from the strong preterit (perfect).

\section{REFERENCES}

Bammesberger, A.

1986

Gotisch (ni) ogs (bus) und althochdeutsch ni kuri. o-o-pe-ro-si. Festschrift für Ernst Risch zum 75. Geburtstag. Berlin, 673-677.

Berg, N.

1977 Der Ursprung des altgriechischen aktiven Plusquamperfekts und die Entwicklung der alphathematischen Flexion. Norsk Tidsskrift for Sprogvidenskap 31, 205-263.

Kortlandt, F. 1989

The Germanic weak preterit. Amsterdamer Beiträge zur älteren Germanistik 28, 101-109.

1990 The Germanic third class of weak verbs. North-Western European Language Evolution 15, 3-10.

1994 The Germanic sixth class of strong verbs. North-Western European Language Evolution 23, 69-73.

Proeme, $\mathrm{H}$. 1984 Thieme, $\mathrm{P}$. 1929 Over de Nederlandse imperativus. Forum der Letteren 25, 241-258. Das Plusquamperfektum im Veda. Göttingen. 